\title{
Proteolytic cleavage of proBDNF into mature BDNF in the basolateral amygdala is necessary for defeat-induced social avoidance
}

\author{
Brooke N. Dulka, Ellen C. Ford, Melissa A. Lee, Nathaniel J. Donnell, Travis D. Goode, \\ Rebecca Prosser, and Matthew A. Cooper \\ University of Tennessee, Knoxville, Tennessee 37996, USA
}

\begin{abstract}
Brain-derived neurotrophic factor (BDNF) is essential for memory processes. The present study tested whether proteolytic cleavage of proBDNF into mature BDNF (mBDNF) within the basolateral amygdala (BLA) regulates the consolidation of defeat-related memories. We found that acute social defeat increases the expression of mBDNF, but not proBDNF, in the $\mathrm{BLA} /$ central amygdala. We also showed that blocking plasmin in the BLA with microinjection of $\alpha_{2}$-antiplasmin immediately following social defeat decreases social avoidance $24 \mathrm{~h}$ later. These data suggest the proteolytic cleavage of BDNF in the BLA is necessary for defeat-induced social avoidance.
\end{abstract}

[Supplemental material is available for this article.]

Brain-derived neurotrophic factor (BDNF), a member of the neurotrophin family, has been identified as a critical molecule underlying synaptic plasticity and memory formation (Bramham and Messaoudi 2005). BDNF, like other neurotrophins, is produced from a large, precursor protein called proBDNF (Yang et al. 2009). ProBDNF requires proteolytic cleavage by plasmin to generate mature BDNF (mBDNF) (Mowla et al. 1999; Pang et al. 2004; Je et al. 2012). ProBDNF preferentially binds to the pan-neurotrophin receptor $\mathrm{p} 75$ ( $\left.\mathrm{p} 75^{\mathrm{NTR}}\right)$, whereas $\mathrm{mBDNF}$ binds to receptor tyrosine kinase TrkB (Woo et al. 2005). While neuronal release of endogenous proBDNF promotes apoptosis (Lee et al. 2001; Teng et al. 2005), the mBDNF-TrkB pathway has been implicated in neuronal growth and survival (Schecterson and Bothwell 1992; Liu et al. 2003). Together, proBDNF and mBDNF and their receptors play bidirectional roles in modulating cell survival and synaptic plasticity, and these opposing actions have led to the "yin and yang" model of neurotrophin activity (Lu et al. 2005).

In the "yin and yang" model, proBDNF represents the "yin" or negative aspect of synaptic plasticity. Treatment of hippocampal slices with proBDNF enhances NMDA receptor-dependent long-term depression (LTD) (Pang et al. 2004). In contrast, mBDNF plays a critical role in long term potentiation (LTP) via activation of TrkB receptors and represents the "yang" or positive aspect of synaptic plasticity (Bramham and Messaoudi 2005; Minichiello 2009). Cleavage of proBDNF into mBDNF is also an important mechanism underlying memory processes. Application of $\alpha_{2}$-antiplasmin, an endogenous compound that inhibits plasmin and thus decreases the cleavage of proBDNF into mBDNF, blocks the induction of LTP in rat hippocampal slices (Mizutani et al. 1996). Furthermore, infusion of $\alpha_{2}$-antiplasmin into the basolateral complex of the amygdala (BLA) prior to fear conditioning significantly reduces fear-potentiated startle (Ou and Gean 2007). These findings indicate an important role for the opposing actions of proBDNF and mBDNF, and that proteolytic cleavage of proBDNF is required for learning and memory.

Corresponding author: bdulka@vols.utk.edu

Article is online at http://www.learnmem.org/cgi/doi/10.1101/lm.040253.115.
Rodent models of acute social defeat provide an ethologically relevant context in which to investigate the mechanisms underlying amygdala-dependent learning. The defeat-induced changes in agonistic behavior that characterize the conditioned defeat response in Syrian hamsters require neural plasticity in the BLA (Jasnow et al. 2005; Markham and Huhman 2008; Day et al. 2011). Similarly, the acquisition and expression of Pavlovian fear conditioning requires neural plasticity in the BLA (Fanselow and Kim 1994; Maren et al. 1996; Josselyn et al. 2001; Rodrigues et al. 2001). Also, BDNF signaling at TrkB receptors in the BLA shortly after treatment is essential for the acquisition of conditioned fear and the effects of acute social defeat stress in Syrian hamsters (Rattiner et al. 2004; Taylor et al. 2011). Models of chronic social defeat in mice have identified BDNF signaling in the nucleus accumbens (NAc) as central for defeat-induced social avoidance, although the mechanisms controlling social avoidance following acute social defeat in mice are unknown. In the present study, we used a mouse model of acute social defeat to investigate whether the conversion of proBDNF into mBDNF within the BLA regulates the consolidation of defeat-related memories. We tested the hypotheses that acute social defeat would increase the expression of proBDNF and mBDNF in the BLA and central amygdala (CeA) complex, and that blocking the conversion of proBDNF into mBDNF in the BLA would disrupt defeat-induced social avoidance.

We first analyzed the expression of proBDNF and mBDNF protein levels in the BLA/CeA after acute social defeat. Mice (C57BL/6; Harlan Laboratories) were subjected to acute social defeat stress using a resident-intruder model adapted from the social defeat literature in Syrian hamsters (Huhman et al. 2003; McCann et al. 2014; Clinard et al. 2015). Social defeat training consisted of three, 2-min aggressive encounters in the home cage of a novel

\footnotetext{
(C) 2016 Dulka et al. This article is distributed exclusively by Cold Spring Harbor Laboratory Press for the first 12 months after the full-issue publication date (see http://learnmem.cshlp.org/site/misc/terms.xhtml). After 12 months, it is available under a Creative Commons License (AttributionNonCommercial 4.0 International), as described at http://creativecommons. org/licenses/by-nc/4.0/.
} 
CD1 resident aggressor mouse with 2-min intertrial intervals in the subjects' home cage. Animals were euthanized 1 or $2 \mathrm{~h}$ following social defeat or empty cage exposure, and tissue punches were collected bilaterally from the BLA/CeA. Western blot assays for proBDNF and mBDNF were performed as previously described (Mou et al. 2009). A detailed Methods section is provided as Supplemental Material. For proBDNF, there was no significant main effect of defeat $\left(F_{(1,37)}=0.29, P=0.60\right)$ or time $\left(F_{(1,37)}=\right.$ $1.51, P=0.23)$; there was also no significant defeat $\times$ time interaction $\left(F_{(1,37)}=0.25, P=0.62\right)($ Fig. $1 \mathrm{~A})$. For mBDNF, there was a significant main effect of defeat $\left(F_{(1,35)}=5.20, P=0.03\right)$ but no main effect of time $\left(F_{(1,35)}=0.001, P=0.97\right)$; there was also no significant defeat $\times$ time interaction $\left(F_{(1,35)}=0.01, P=0.91\right)$ (Fig. 1B). Taken together, these data indicate that acute social defeat stress

A
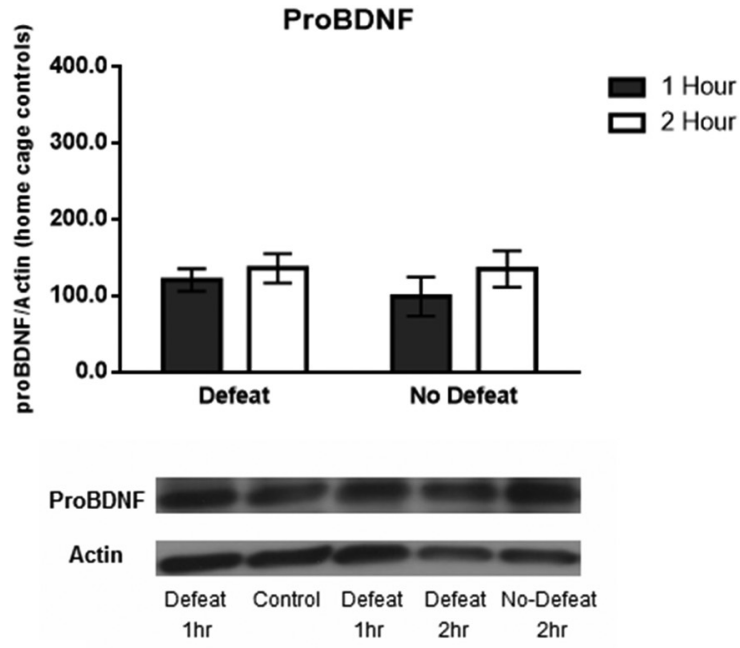

B
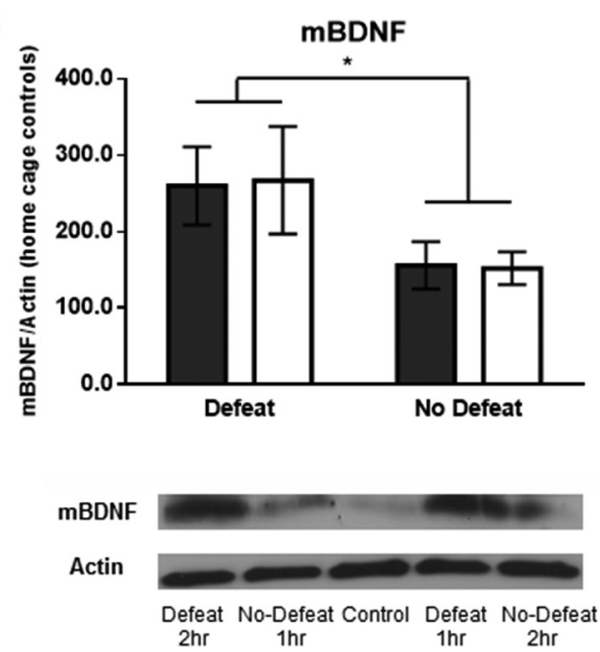

Figure 1. Effects of social defeat on pro- and mature BDNF expression in the BLA/CeA complex. (A) Social defeat has no effect on the expression of proBDNF in the BLA/CeA complex. (B) Social defeat increased the expression of mBDNF in the BLA/CeA complex both 1 and $2 \mathrm{~h}$ after defeat. *Indicates a main effect of social defeat $(P<0.05)$. Protein samples were incubated overnight at $4^{\circ} \mathrm{C}$ with rabbit antiBDNF $(1: 1000$, Santa Cruz Biotechnology). The optical densities of pro- and mature BDNF bands were normalized to the corresponding $\beta$-actin band for each sample. Results are expressed as mean percentages of home cage control values $( \pm S E M)$. Blots have been cropped for clarity to create representative gel patterns. increased the expression of mBDNF, but not proBDNF, in the BLA/CeA complex both 1 and $2 \mathrm{~h}$ after defeat.

If the conversion of proBDNF into $\mathrm{mBDNF}$ in the BLA is necessary for defeat-induced social avoidance, then infusion of a plasmin inhibitor such as $\alpha_{2}$-antiplasmin following social defeat should impair social avoidance. In the following experiment, subjects were bilaterally infused with $\alpha_{2}$-antiplasmin (300 ng) or vehicle into the BLA immediately following social defeat. No-defeat controls also received bilateral infusions of $\alpha_{2}$-antiplasmin (300 $\mathrm{ng}$ ) or vehicle immediately following their final empty cage exposure. This post-training time point was chosen in order to target the early stages of memory consolidation. Social avoidance testing occurred $24 \mathrm{~h}$ after defeat and was modeled after both conditioned defeat testing in Syrian hamsters and social avoidance testing in mice (Huhman et al. 2003; Golden et al. 2011; McCann et al. 2014; see Supplemental Material). We found a significant drug $\times$ defeat interaction for the total time spent in the nest zone during the target present trial $\left(F_{(1,47)}=4.68\right.$, $P=0.036$; Fig. 2B). Defeated animals that were given saline spent more time in the nest zone compared with defeated animals given $\alpha_{2}$-antiplasmin, whereas control animals did not differ. Similarly, there was a significant drug $\times$ defeat interaction for the total time spent in the interaction zone $\left(F_{(1,47)}=4.70, P=0.035\right.$; Fig. 2C). Defeated, saline-treated animals spent less time in the interaction zone compared with defeated, drug-treated animals, whereas control animals did not differ. We also quantified the number of physical contacts subjects made with the stimulus box and found a main effect of both drug $\left(F_{(1,47)}=5.89, P=0.019\right)$ and defeat $\left(F_{(1,47)}=11.40, \quad P=0.001\right)$ although the interaction $\left(F_{(1,47)}=1.65, P=0.205\right)$ did not reach statistical significance (Fig. 2D). During the target absent trial, there were no significant differences in time spent in the nest zone, interaction zone, or physical contacts with the stimulus box $(P>0.05)$. Because no significant differences were found during the target absent trials, the differences in behavior observed during the target present trials were a result of the CD1 animals' presence and not preexisting dispositions of subjects. Overall, these data indicate that $\alpha_{2}$-antiplasmin treatment immediately following social defeat prevented defeat-induced social avoidance and suggest that conversion of proBDNF into mBDNF in the BLA by plasmin is necessary for the consolidation of a defeat-related memory.

We analyzed animals with misplaced cannula as anatomical controls, and the majority of these animals had injections into the endopiriform claustrum, piriform cortex, and lateral ventricles (Fig. 3; Supplemental Table 1). In animals with bilateral injections outside the BLA there was no significant effect of $\alpha_{2}$-antiplasmin on the total time in the nest zone $\left(F_{(1,28)}=0.25\right.$, $P=0.623)$, although there was a main effect of defeat $\left(F_{(1,28)}=\right.$ $13.49, P=0.001)$. Likewise, there was no significant effect of $\alpha_{2}$-antiplasmin on total time in the interaction zone in animals with bilateral misses $\left(F_{(1,28)}=0.85, P=0.366\right)$, although there was a main effect of defeat $\left(F_{(1,28)}=15.12, P=0.001\right)$. In other words, defeated, $\alpha_{2}$-antiplasmin treated animals with bilateral misses spent more time in the nest zone and less time in the interaction zone than nondefeated animals. These results indicate that the ability of $\alpha_{2}$-antiplasmin to reduce defeat-induced social avoidance requires injection within the BLA.

Altogether, our findings suggest that inhibiting the conversion of proBDNF into mBDNF immediately following social defeat disrupts the consolidation of a defeat-related memory. These results suggest a critical role for mBDNF activity within the BLA underlying memory for acute traumatic events. Similar cellular and molecular mechanisms within the BLA likely regulate responses to acute social defeat in several rodent species. We found that the majority of defeated, saline-treated mice displayed robust social avoidance $24 \mathrm{~h}$ after social defeat. This defeat-induced change 
A

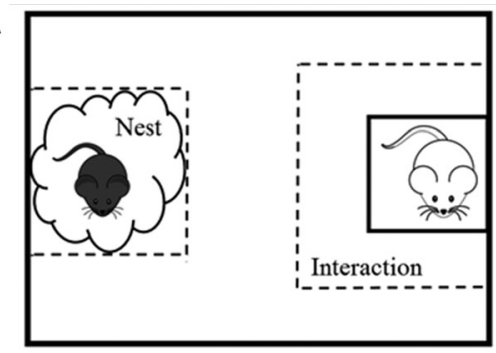

C

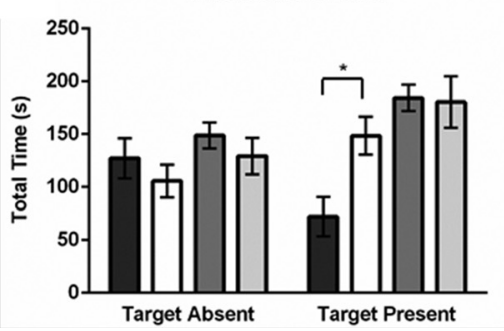

B

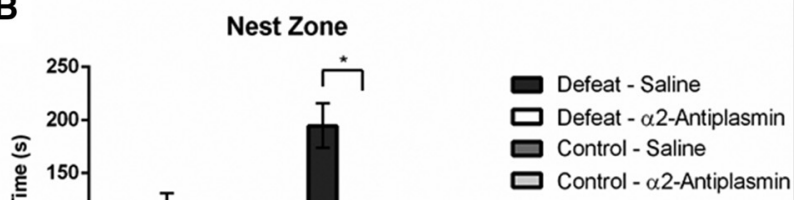

Figure 2. Subjects were bilaterally implanted with 26-gauge guide cannula and received infusion of $\alpha_{2}$-antiplasmin ( $300 \mathrm{ng}$ in $0.1 \mu \mathrm{L}$ sterile saline) or saline into the BLA immediately following social defeat or empty cage exposure. (A) A diagram of the subject's home cage during social avoidance testing. The dotted lines represent the nest zone and interaction zone. (B) Defeated, saline treated animals spent more time in the nest zone compared with defeated, $\alpha_{2}$-antiplasmin treated animals. (C) Defeated, saline treated animals spent less time in the interaction zone compared with defeated, $\alpha_{2}$-antiplasmin treated animals. (D) Defeated animals made fewer contacts with the box in the target present condition compared with nondefeated controls. Data are shown as mean \pm SEM. ${ }^{*}$ Indicates a significant drug $\times$ defeat interaction $(P<0.05) .{ }^{* *}$ Indicates a significant main effect of defeat $(P<0.001)$.

in social motivation is similar to the avoidance and submissive/ defensive behavior displayed by Syrian hamsters after acute social defeat (McCann et al. 2014; Clinard et al. 2015). Other studies using mice indicate that three 2-min social defeat encounters lead to avoidance of odor for familiar aggressors as well as increased c-Fos in the BLA, medial prefrontal cortex, and CA1 layer of the hippocampus (Bourne et al. 2013). In Syrian hamsters, a single social defeat increases c-Fos in several brain regions including the BLA, CeA, medial amygdala, and bed nucleus of the stria terminalis (BNST) (Markham et al. 2010), and the conditioned defeat response is regulated, in part, by BDNF-TrkB signaling in the BLA (Taylor et al. 2011). Similarly, in Sprague-Dawley rats, four social defeat episodes at $72 \mathrm{~h}$ intervals have been shown to increase BDNF mRNA in the BLA, although BDNF protein levels were decreased (Fanous et al. 2010). Interestingly, in this rat model of social defeat stress aggressive encounters are stopped after losers display a full supine posture and thus the defeat experience is of low intensity (Tornatzky and Miczek 1993). Altogether these findings suggest that the BDNF activity in the BLA is a critical factor regulating responses to acute and/or low intensity social defeat stress.

BDNF signaling also regulates changes in anxiety-like and depression-like behavior following chronic social defeat stress. Following $10 \mathrm{~d}$ of chronic social defeat, susceptible mice exhibit increased firing rates of ventral tegmental area (VTA) dopaminergic neurons and increased release of BDNF into projection regions including the NAc (Berton et al. 2006; Krishnan et al. 2007). While these studies did not differentiate proBDNF and mBDNF, they indicate that susceptible, but not resistant, mice exhibit enhanced BDNF activity in a VTA to NAc pathway. Also, chronic social defeat models have used a subthreshold defeat experience when examining treatments that may promote susceptibility. Three, 5-min social defeats with a 5-min rest period between each defeat episode fail to produce social avoidance $24 \mathrm{~h}$ later (Krishnan et al. 2007; Christoffel et al. 2011), although acute optogenetic stimulation of the VTA-NAc pathway does lead to social avoidance (Wook
Koo et al. 2016). The procedure used in our study differs from the subthreshold defeat experience insofar as we used three, 2-min social defeats with a 2-min rest period between defeats. We also used a 10-min social interaction test (5-min target absent and 5-min target present) in the home cage rather than a 5-min test in a neutral arena. However, the testing arena may have a limited effect on defeat-induced social avoidance as we found that defeated mice exhibit robust social avoidance in both home cage and neutral arena testing environments (Supplemental Figure 1). In any case, other social defeat models in mice have used a repeated defeat procedure, in part, to overcome the variability of acute social defeat. In C57 mice, four social defeat episodes per day for two consecutive days lead to social avoidance that persists for at least $30 \mathrm{~d}$ (Meduri et al. 2013). In California mice, one social defeat episode per day for three consecutive days leads to long-lasting social avoidance and increased mBDNF expression in the anterior BNST in females, but not males (Greenberg et al. 2014).

BDNF-TrkB signaling in the BLA and hippocampus is known to regulate the synaptic plasticity controlling the acquisition and extinction of conditioned fear. In rats, TrkB receptor activity in the BLA is necessary for the acquisition of a fear memory (Rattiner et al. 2004), as well as the consolidation of a stable extinction memory (Chhatwal et al. 2006). BDNF protein within the dorsal hippocampus is also necessary for the consolidation of contextual fear memories (Lee et al. 2004). Treatments that prevent the conversion of proBDNF to mBDNF, as well as those that block TrkB receptors, have been shown to decrease LTP in hippocampal slices (Figurov et al. 1996; Mizutani et al. 1996; Kang et al. 1997; Pang et al. 2004). Overall, our findings support the "yin and yang" model of neurotrophin action and suggest that $\alpha_{2}$-antiplasmin injection may have impaired the consolidation of a defeat-related memory by reducing mBDNF-TrkB signaling in the BLA. Alternatively, the decreased proteolytic cleavage of proBDNF could have impaired memory consolidation by producing an excess of proBDNF and led to increased LTD via a 


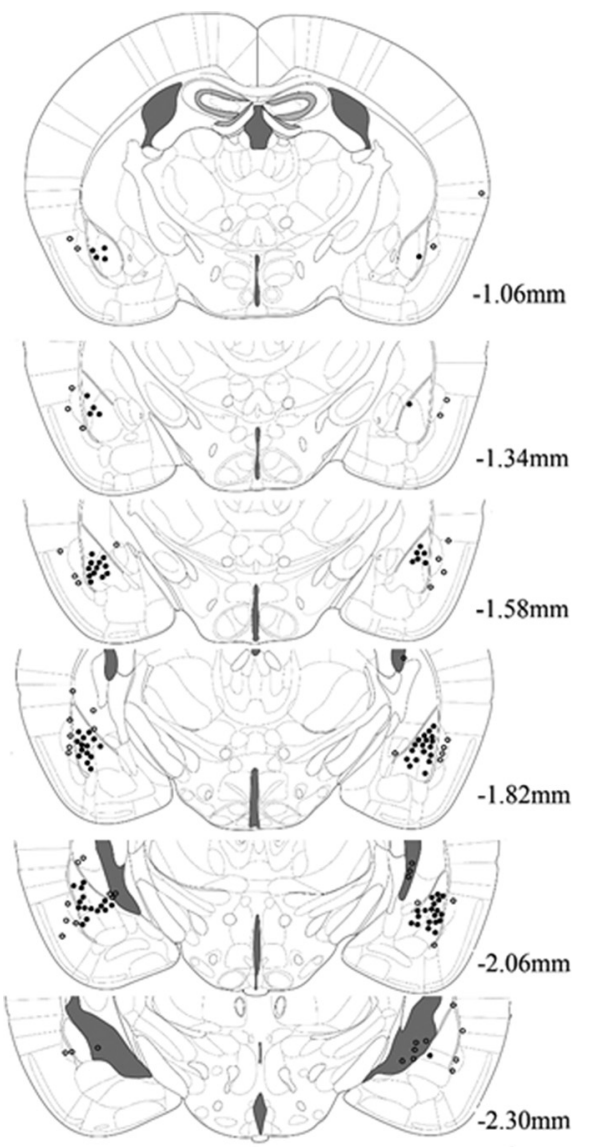

Figure 3. Histological localization of bilateral hits and misses. The distances shown for each coronal section are relative to bregma. Black circles represent approximate injection sites within the BLA; open circles represent injection sites for anatomical controls. Schematic drawings of coronal sections of the mouse brain adapted from the atlas of Franklin and Paxinos (1997) with permission from Elsevier 1997.

proBDNF-p75 ${ }^{\text {NTR }}$ signaling pathway (Woo et al. 2005). While post-training drug injections target memory consolidation, future studies with $\alpha_{2}$-antiplasmin injection outside of a memory consolidation time window would be necessary to rule out retrieval processes. Nevertheless, $\alpha_{2}$-antiplasmin likely impaired the formation of defeat-induced memories because it prevented the ability of plasmin to cleave proBDNF into mBDNF. Although $\alpha_{2^{-}}$ antiplasmin is an endogenous compound that is highly selective for plasmin, it is worth nothing that $\alpha_{2}$-antiplasmin also inhibits enzymes such as chymotrypsin and trypsin (Potempa et al. 1988). Finally, although the primary role of plasmin is to cleave proBDNF into mBDNF, it may also cleave the NR1 (Samson et al. 2008) and NR2A (Yuan et al. 2009) subunits of NMDA receptors, as well as matrix metallopeptidase-9 (Van den Steen et al. 2002).

Our data are also consistent with previous research suggesting that proBDNF is released and processed extracellularly in the hippocampus (Mowla et al. 1999, 2001). Because we found that social defeat leads to increased expression of mBDNF, but no change in proBDNF, it is possible that social defeat stress increases the proteolytic cleavage of proBDNF. Others have shown that social defeat increases BDNF mRNA (Taylor et al. 2011), however we did not find a change in the expression of proBDNF in the BLA/CeA complex. It is possible that an increase in proBDNF production was offset by increased conversion into mBDNF. Alternatively, animals may have a large reservoir of proBDNF pro- tein, which obscures defeat-induced changes in protein expression. In addition, $\alpha_{2}$-antiplasmin may act as an endogenous modulator of memory and anxiety-related behavior. Knockout of the $\alpha_{2}$-antiplasmin gene results in deficits in spatial memory in a Morris water maze, impairs learning in both contextual and cued fear conditioning tasks, and induces anxiety-like behavior in an open field and light-dark transition test (Kawashita et al. 2014). Further research is needed to determine whether experience-dependent changes in endogenous $\alpha_{2}$-antiplasmin activity can modulate BDNF signaling and subsequent changes in behavior.

In sum, social defeat increases the expression of mBDNF in the BLA/CeA complex, and infusion of $\alpha_{2}$-antiplasmin into the BLA immediately following social defeat reduces social avoidance. These data suggest that blocking the conversion of proBDNF into mBDNF in the BLA disrupts the consolidation of defeat-related memories. Finally, these results suggest that the BDNF proteolytic pathway is a novel target for modulating emotional memories and treating stress-related psychiatric disorders.

\section{Acknowledgments}

This research is supported by NARSAD grant 19260 from the Brain and Behavior Research Foundation to M.A.C. We would like to thank our team of undergraduate students for their daily technical assistance, including Samuel Adler, Sahba Seddighi, and Lauren Debusk.

\section{References}

Berton O, McClung CA, Dileone RJ, Krishnan V, Renthal W, Russo SJ, Graham D, Tsankova NM, Bolanos CA, Rios M, et al. 2006. Essential role of BDNF in the mesolimbic dopamine pathway in social defeat stress. Science 311: $864-868$.

Bourne AR, Mohan G, Stone MF, Pham MQ, Schultz CR, Meyerhoff JL, Lumley LA. 2013. Olfactory cues increase avoidance behavior and induce Fos expression in the amygdala, hippocampus and prefrontal cortex of socially defeated mice. Behav Brain Res 256: 188-196.

Bramham CR, Messaoudi E. 2005. BDNF function in adult synaptic plasticity: the synaptic consolidation hypothesis. Prog Neurobiol 76: 99-125.

Chhatwal JP, Stanek-Rattiner L, Davis M, Ressler KJ. 2006. Amygdala BDNF signaling is required for consolidation but not encoding of extinction. Nat Neurosci 9: 870-872.

Christoffel DJ, Golden SA, Dumitriu D, Robison AJ, Janssen WG, Ahn HF, Krishnan V, Reyes CM, Han M-H, Ables JL. 2011. IкB kinase regulates social defeat stress-induced synaptic and behavioral plasticity. $J$ Neurosci 31: 314-321.

Clinard CT, Bader LR, Sullivan MA, Cooper MA. 2015. Activation of 5-HT2a receptors in the basolateral amygdala promotes defeat-induced anxiety and the acquisition of conditioned defeat in Syrian hamsters. Neuropharmacology 90: 102-112.

Day DE, Cooper MA, Markham CM, Huhman KL. 2011. NR2B subunit of the NMDA receptor in the basolateral amygdala is necessary for the acquisition of conditioned defeat in Syrian hamsters. Behav Brain Res 217: $55-59$.

Fanous S, Hammer R, Nikulina EM. 2010. Short- and long-term effects of intermittent social defeat stress on brain-derived neurotrophic factor expression in mesocorticolimbic brain regions. Neuroscience 167: 598-607.

Fanselow MS, Kim JJ. 1994. Acquisition of contextual Pavlovian fear conditioning is blocked by application of an NMDA receptor antagonist D, L-2-amino-5-phosphonovaleric acid to the basolateral amygdala. Behav Neurosci 108: 210.

Figurov A, Pozzo-Miller LD, Olafsson P, Wang T, Lu B. 1996. Regulation of synaptic responses to high-frequency stimulation and LTP by neurotrophins in the hippocampus. Nature 381: 706-709.

Franklin BJ, Paxinos G. 1997. The mouse brain in stereotaxic coordinates. Academic Press, San Diego, CA.

Golden SA, Covington HE III, Berton O, Russo SJ. 2011. A standardized protocol for repeated social defeat stress in mice. Nat Protoc 6: $1183-1191$.

Greenberg GD, Laman-Maharg A, Campi KL, Voigt H, Orr VN, Schaal L, Trainor BC. 2014. Sex differences in stress-induced social withdrawal: 
role of brain derived neurotrophic factor in the bed nucleus of the stria terminalis. Front Behav Neurosci 7: 223.

Huhman KL, Solomon MB, Janicki M, Harmon AC, Lin SM, Israel JE, Jasnow AM. 2003. Conditioned defeat in male and female Syrian hamsters. Horm Behav 44: 293-299.

Jasnow AM, Shi C, Israel JE, Davis M, Huhman KL. 2005. Memory of social defeat is facilitated by cAMP response element-binding protein overexpression in the amygdala. Behav Neurosci 119: 1125-1130.

Je HS, Yang F, Ji Y, Nagappan G, Hempstead BL, Lu B. 2012. Role of pro-brain-derived neurotrophic factor (proBDNF) to mature BDNF conversion in activity-dependent competition at developing neuromuscular synapses. Proc Natl Acad Sci 109: 15924-15929.

Josselyn SA, Shi C, Carlezon WA Jr, Neve RL, Nestler EJ, Davis M. 2001. Long-term memory is facilitated by cAMP response element-binding protein overexpression in the amygdala. J Neurosci 21: 2404-2412.

Kang H, Welcher AA, Shelton D, Schuman EM. 1997. Neurotrophins and time: different roles for TrkB signaling in hippocampal long-term potentiation. Neuron 19: 653-664.

Kawashita E, Kanno Y, Ikeda K, Kuretake H, Matsuo O, Matsuno H. 2014. Altered behavior in mice with deletion of the $\alpha 2$-antiplasmin gene. PLoS One 9: e97947.

Krishnan V, Han MH, Graham DL, Berton O, Renthal W, Russo SJ, Laplant Q, Graham A, Lutter M, Lagace DC, et al. 2007. Molecular adaptations underlying susceptibility and resistance to social defeat in brain reward regions. Cell 131: 391-404.

Lee R, Kermani P, Teng KK, Hempstead BL. 2001. Regulation of cell survival by secreted proneurotrophins. Science 294: $1945-1948$.

Lee JL, Everitt BJ, Thomas KL. 2004. Independent cellular processes for hippocampal memory consolidation and reconsolidation. Science 304: 839-843.

Liu L, Cavanaugh JE, Wang Y, Sakagami H, Mao Z, Xia Z. 2003. ERK5 activation of MEF2-mediated gene expression plays a critical role in BDNF-promoted survival of developing but not mature cortical neurons. Proc Natl Acad Sci 100: 8532-8537.

Lu B, Pang PT, Woo NH. 2005. The yin and yang of neurotrophin action. Nat Rev Neurosci 6: 603-614.

Maren S, Aharonov G, Stote DL, Fanselow MS. 1996. N-methyl-D-aspartate receptors in the basolateral amygdala are required for both acquisition and expression of conditional fear in rats. Behav Neurosci 110: $1365-1374$.

Markham CM, Huhman KL. 2008. Is the medial amygdala part of the neural circuit modulating conditioned defeat in Syrian hamsters? Learn Mem 15: 6-12.

Markham CM, Taylor SL, Huhman KL. 2010. Role of amygdala and hippocampus in the neural circuit subserving conditioned defeat in Syrian hamsters. Learn Mem 17: 109-116.

McCann KE, Bicknese CN, Norvelle A, Huhman KL. 2014. Effects of inescapable versus escapable social stress in Syrian hamsters: the importance of stressor duration versus escapability. Physiol Behav 129: 25-29.

Meduri JD, Farnbauch LA, Jasnow AM. 2013. Paradoxical enhancement of fear expression and extinction deficits in mice resilient to social defeat. Behav Brain Res 256: 580-590.

Minichiello L. 2009. TrkB signalling pathways in LTP and learning. Nat Rev Neurosci 10: $850-860$.

Mizutani A, Saito H, Matsuki N. 1996. Possible involvement of plasmin in long-term potentiation of rat hippocampal slices. Brain Res 739: $276-281$.

Mou X, Peterson CB, Prosser RA. 2009. Tissue-type plasminogen activatorplasmin-BDNF modulate glutamate-induced phase-shifts of the mouse suprachiasmatic circadian clock in vitro. Eur J Neurosci 30: 1451-1460.
Mowla SJ, Pareek S, Farhadi HF, Petrecca K, Fawcett JP, Seidah NG, Morris SJ, Sossin WS, Murphy RA. 1999. Differential sorting of nerve growth factor and brain-derived neurotrophic factor in hippocampal neurons. J Neurosci 19: 2069-2080.

Mowla SJ, Farhadi HF, Pareek S, Atwal JK, Morris SJ, Seidah NG, Murphy RA. 2001. Biosynthesis and post-translational processing of the precursor to brain-derived neurotrophic factor. J Biol Chem 276: 12660-12666.

Ou L-C, Gean P-W. 2007. Transcriptional regulation of brain-derived neurotrophic factor in the amygdala during consolidation of fear memory. Mol Pharmacol 72: 350-358.

Pang PT, Teng HK, Zaitsev E, Woo NT, Sakata K, Zhen S, Teng KK, Yung WH, Hempstead BL, Lu B. 2004. Cleavage of proBDNF by tPA/Plasmin is Essential for Long-Term Hippocampal Plasticity. Science 306: 487-491.

Potempa J, Shieh BH, Travis J. 1988. $\alpha$-2-antiplasmin: a serpin with two separate but overlapping reactive sites. Science 241: 699-700.

Rattiner LM, Davis M, French CT, Ressler KJ. 2004. Brain-derived neurotrophic factor and tyrosine kinase receptor B involvement in amygdala-dependent fear conditioning. J Neurosci 24: 4796-4806.

Rodrigues SM, Schafe GE, LeDoux JE. 2001. Intra-amygdala blockade of the NR2B subunit of the NMDA receptor disrupts the acquisition but not the expression of fear conditioning. J Neurosci 21: 6889-6896.

Samson AL, Nevin ST, Croucher D, Niego B, Daniel PB, Weiss TW, Moreno E, Monard D, Lawrence DA, Medcalf RL. 2008. Tissue-type plasminogen activator requires a co-receptor to enhance NMDA receptor function. J Neurochem 107: 1091-1101.

Schecterson LC, Bothwell M. 1992. Novel roles for neurotrophins are suggested by BDNF and NT-3 mRNA expression in developing neurons. Neuron 9: 449-463.

Taylor SL, Stanek LM, Ressler KJ, Huhman KL. 2011. Differential brain-derived neurotrophic factor expression in limbic brain regions following social defeat or territorial aggression. Behav Neurosci 125: 911-920.

Teng HK, Teng KK, Lee R, Wright S, Tevar S, Almeida RD, Kermani P, Torkin R, Chen Z-Y, Lee FS, et al. 2005. ProBDNF induces neuronal apoptosis via activation of a receptor complex of p75NTR and sortilin. $J$ Neurosci 25: 5455-5463.

Tornatzky W, Miczek KA. 1993. Long-term impairment of autonomic circadian rhythms after brief intermittent social stress. Physiol Behav 53: $983-993$.

Van den Steen PE, Dubois B, Nelissen I, Rudd PM, Dwek RA, Opdenakker G. 2002. Biochemistry and molecular biology of gelatinase B or matrix metalloproteinase-9 (MMP-9). Crit Rev Biochem Mol Biol 37: 375-536.

Woo NH, Teng HK, Siao CJ, Chiaruttini C, Pang PT, Milner TA, Hempstead BL, Lu B. 2005. Activation of p75NTR by proBDNF facilitates hippocampal long-term depression. Nat Neurosci 8: 1069-1077.

Wook Koo J, Labonté B, Engmann O, Calipari ES, Juarez B, Lorsch Z, Walsh JJ, Friedman AK, Yorgason JT, Han M-H, et al. 2016. Essential role of mesolimbic brain-derived neurotrophic factor in chronic social stress-induced depressive behaviors. Biol Psychiatry.

Yang J, Siao CJ, Nagappan G, Marinic T, Jing D, McGrath K, Chen ZY, Mark W, Tessarollo L, Lee FS, et al. 2009. Neuronal release of proBDNF. Nat Neurosci 12: 113-115.

Yuan H, Vance KM, Junge CE, Geballe MT, Snyder JP, Hepler JR, Yepes M, Low C-M, Traynelis SF. 2009. The serine protease plasmin cleaves the amino-terminal domain of the NR2A subunit to relieve zinc inhibition of the N-methyl-D-aspartate receptors. J Biol Chem 284: 12862-12873.

Received September 21, 2015; accepted in revised form January 21, 2016. 


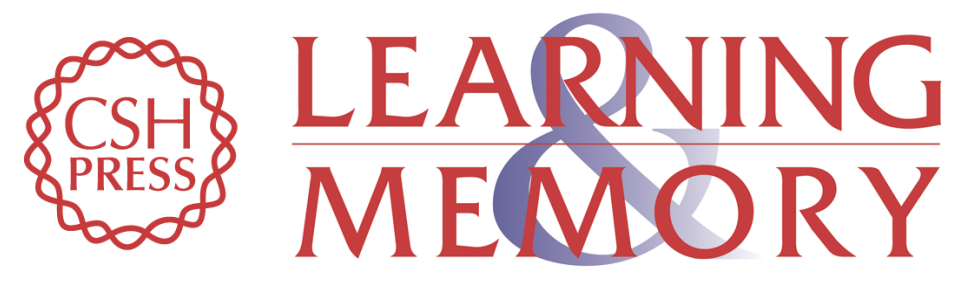

\section{Proteolytic cleavage of proBDNF into mature BDNF in the basolateral amygdala is necessary for defeat-induced social avoidance}

Brooke N. Dulka, Ellen C. Ford, Melissa A. Lee, et al.

Learn. Mem. 2016, 23:

Access the most recent version at doi:10.1101/Im.040253.115

\section{Supplemental http://learnmem.cshlp.org/content/suppl/2016/03/10/23.4.156.DC1 \\ Material}

References This article cites 47 articles, 18 of which can be accessed free at: http://learnmem.cshlp.org/content/23/4/156.full.html\#ref-list-1

Creative This article is distributed exclusively by Cold Spring Harbor Laboratory Press for the Commons first 12 months after the full-issue publication date (see License http://learnmem.cshlp.org/site/misc/terms.xhtml). After 12 months, it is available under a Creative Commons License (Attribution-NonCommercial 4.0 International), as described at http://creativecommons.org/licenses/by-nc/4.0/.

Email Alerting Receive free email alerts when new articles cite this article - sign up in the box at the Service top right corner of the article or click here. 